\title{
Investigation and Improvement of the Electrical Performance of Silicon Solar Cells
}

\author{
Soha M. Abd El-Azeem (1), S.M. El-Ghanam ${ }^{(1)}$, S.A.Kamh ${ }^{(1)}$, and F.A.S.Soliman ${ }^{(2)}$ \\ 1- Electronic Res. Lab., Women's Collage for Art, Science, and Education, Ain-Shams Univ., Cairo, \\ Egypt. \\ 2- Nuclear Materials Authority, P. O. Box 530-Maadi, Maadi, Cairo, Egypt.
}

\begin{abstract}
The present paper focuses on the investigation and improvement of the electrical performance of photovoltaic mono-crystalline silicon solar cells. Where, temperature effect was studied in details, where cells loss were observed, analyzed, and several trials to reduce its value were investigated applying passive and active aluminum heat sinks. Also, introduction of thermoelectric generators was proved to pronouncedly enhance the cells performances. The dependences of the opencircuit voltage, maximum output power, short-circuit current, and power conversion efficiency on temperature were observed. Where, their values were reported to be in the order of $-2.3 \mathrm{mV} /{ }^{\circ} \mathrm{C},-0.59$ $\mathrm{mW} /{ }^{\circ} \mathrm{C},+0.22 \mathrm{~mA} /{ }^{\circ} \mathrm{C}$, and $0.065 \% /{ }^{\circ} \mathrm{C}$, measured for free $\mathrm{PV}$, and cell temperature of $39.0{ }^{\circ} \mathrm{C}$. The maximum output power and conversion efficiency of the cell were shown to be reduced down to $-0.53 \mathrm{~mW} /{ }^{\circ} \mathrm{C}$ and $-0.058 \% /{ }^{\circ} \mathrm{C}$, measured for the solar cell/thermoelectric hybrid system. Moreover, for solar cell/thermoelectric/passive heat sink hybrid system, their values were shown to be $-0.52 \mathrm{~mW} /{ }^{\circ} \mathrm{C}$ and $-0.057 \% /{ }^{\circ} \mathrm{C}$. Finally, for the solar cell/thermoelectric/active heat sink hybrid system, the values reach $-0.34 \mathrm{~mW} /{ }^{\circ} \mathrm{C}$ and $0.037 \% /{ }^{\circ} \mathrm{C}$, respectively.
\end{abstract}

Keywords: Silicon, solar cell, photovoltaic effect, thermoelectric generator, open-circuit voltage, short-circuit current, efficiency, and aluminum heat sink.

\subsection{Introduction}

The photovoltaic effect refers to the electromotive force generated at metal semi-conductor and semiconductor junctions upon excitation by electromagnetic radiation [1]. A solar cell (also called a photovoltaic cell) is an electrical device that converts the energy of light directly into electricity in the form of photocurrent by the photovoltaic effect [2]. The equivalent circuit of an ideal solar cell [3] is shown in Fig. (1). The output power of crystalline silicon solar cells decreases significantly with increased temperature with about a $0.40-0.50 \%$ loss for every degree Celsius [4-6]. This drop in the output power is mainly due to the open circuit voltage $\left(\mathrm{V}_{\mathrm{oc}}\right.$, which also goes down by about 0.40 $\% /{ }^{\circ} \mathrm{C}$, the matter is due to the increased recombination in the semiconductor at higher temperatures stemming from the greater prevalence of phonons [7]. 


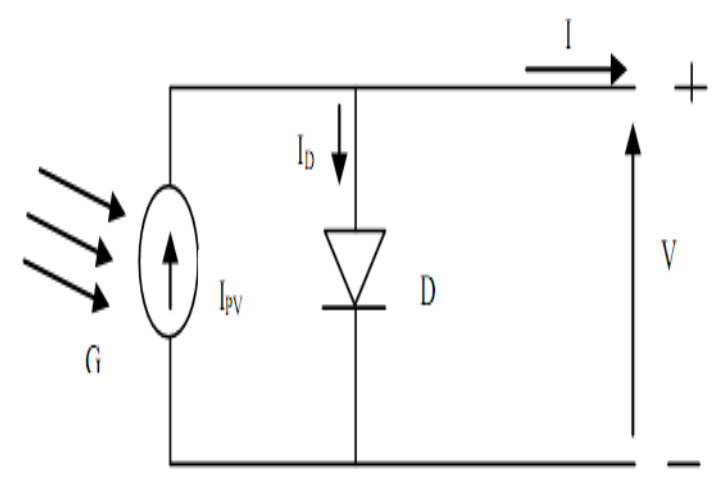

Fig. (1) Equivalent circuit of silicon solar cell.

The efficiency ( $\eta$ ) of a solar cell (Eq.1) is an important parameter to compare the performance of one solar cell to another. It could be defined as the ratio of the photo-voltaically generated electric output power $\left(\mathrm{P}_{\max }\right)$ from the solar cell to that energy $\left(\mathrm{P}_{\mathrm{in}}\right)$ received from the sun [8].

$$
\eta=\frac{P_{\max }}{P_{i n}}=\frac{V o c * I S C * F F}{P_{i n}}
$$

Where; FF: Fill Factor and could be determined from Eq. (2).

$$
F F=\frac{V_{M P *} I_{M P}}{V_{o c *} I_{S C}}
$$

Where:

$\mathrm{I}_{\mathrm{sc}}$ : Short-circuit current

$\mathrm{V}_{\mathrm{MP}}$ : Maximum voltage and

$\mathrm{I}_{\mathrm{MP}}$ : Maximum current.

\subsection{Experimental}

\subsection{Output Characteristics}

During the course of the study, Si- solar cell samples and thermoelectric devices were used. The solar cells are mono-crystalline silicon with $5.70 \mathrm{~cm}$ in diameter, manufactured by Sargent - Welch (Fig. 2a), while, thermoelectric samples (TE) were of the type 06311-5L31-02CDK (Fig. 2b), manufactured by Customer Thermoelectric, Inc. [9]. The thermal and electrical performances of the solar cells were investigated, applying the circuit shown in Fig. (3). In this concern, the (I-V) characteristic curves [10] were plotted under different illumination levels. Also, the effect of the cell temperature on the different electrical parameters [11] was studied under different operating conditions (Table 1). 


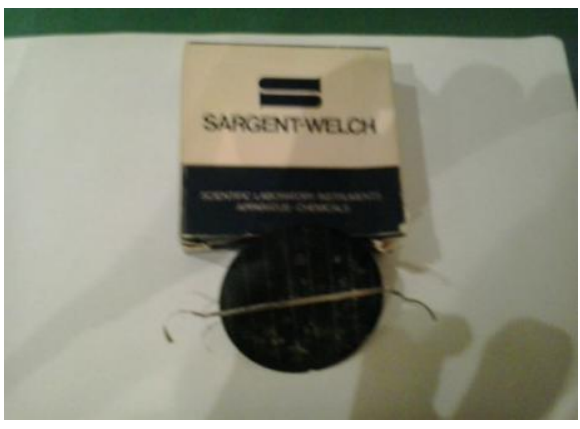

(a)

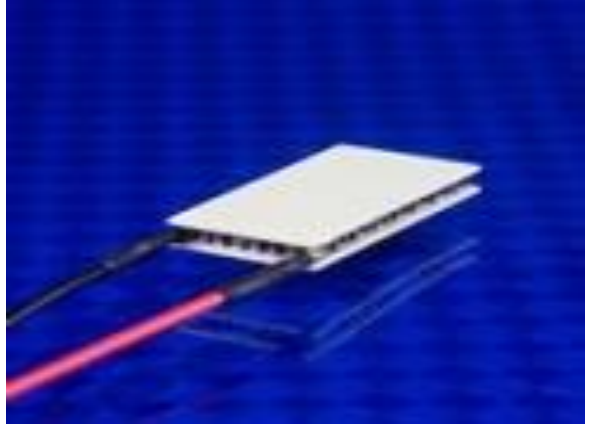

(b)

Fig. (2) Sargent-Welch solar cell of $5.70 \mathrm{~cm}$ in diameter (a), and thermoelectric sample of the type 06311-5L31-02CDK (b).

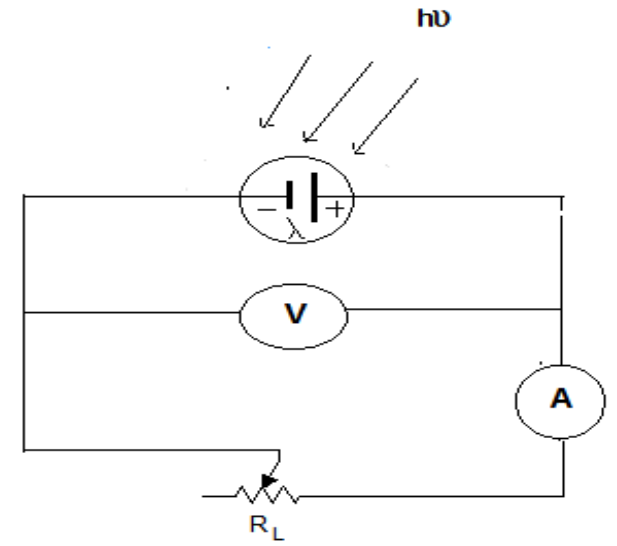

Fig. (3) Circuit used for studying the output electrical parameters of the solar cell under different illumination levels.

Table (1): Operating conditions used during solar cell characterization.

\begin{tabular}{|ccc|}
\hline Operating Conditions & Operating Parameters & Parameters Conditions \\
\hline hybrid PV & Illumination level & 36.0 klux \\
\hline PV / TE & Illumination level & 36.0 klux \\
\hline PV/TE/passive heat sink (Fig. 4a) & $\begin{array}{c}\text { Al-heat sink } \\
\text { Illumination level }\end{array}$ & $36.0 \mathrm{~cm}^{2}+36.0 \mathrm{klux}$ \\
& $\begin{array}{c}\text { Heat sink +Air speed }+ \\
\text { Illumination level }\end{array}$ & $\mathbf{3 6 . 0} \mathrm{cm}^{2}+36.0 \mathrm{klux}+2.36 \mathrm{~m} / \mathrm{sec}$ \\
\hline PV/TE/active heat sink (Fig. 4b) & & \\
\hline
\end{tabular}

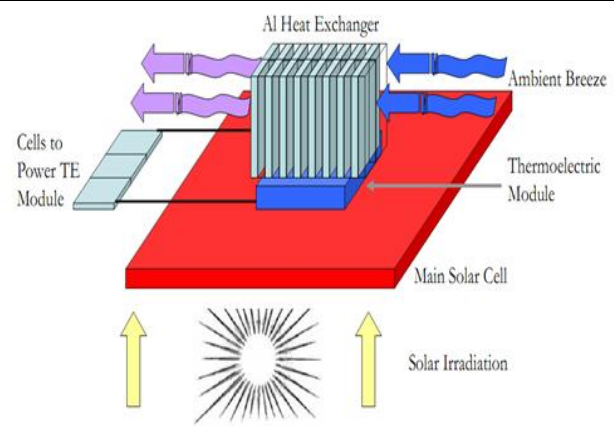

(a)

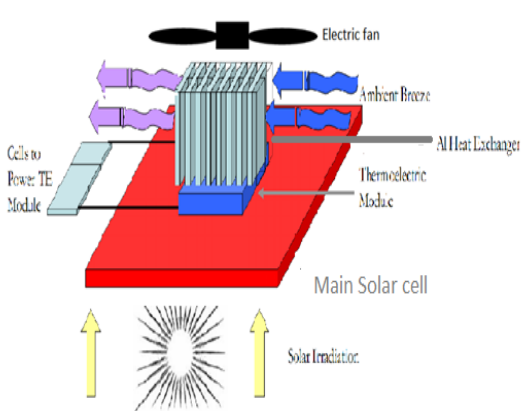

(b)

Fig. (4) PV/TE/passive heat sink (a)-, and PV/TE/active heat sink (b)- hybrid systems. 


\subsection{Temperature Effects}

The dependence of the electrical parameters of the proposed solar cells on temperature was studied. In this concern, the sample was kept running at different illumination levels while recording, periodically, their output parameters and temperature.

\subsection{Characteristics of Mono-Crystalline Si- Solar Cell 3.1. Output Characteristics}

The output current-voltage (I-V) characteristic curves of the proposed silicon solar cells were plotted at different illumination levels (Fig. 5). From which, it is clearly shown that, the short-circuit current $\left(\mathrm{I}_{\mathrm{sc}}\right)$ and open-circuit voltage $\left(\mathrm{V}_{\mathrm{oc}}\right)$ increase with increasing illumination level, where their values increased from $160 \mathrm{~mA}$ and 0.40 Volt, measured at illumination level of 1.90 klux, up to 560 $\mathrm{mA}$ and 0.456 Volt, measured at 44.30 klux, respectively.

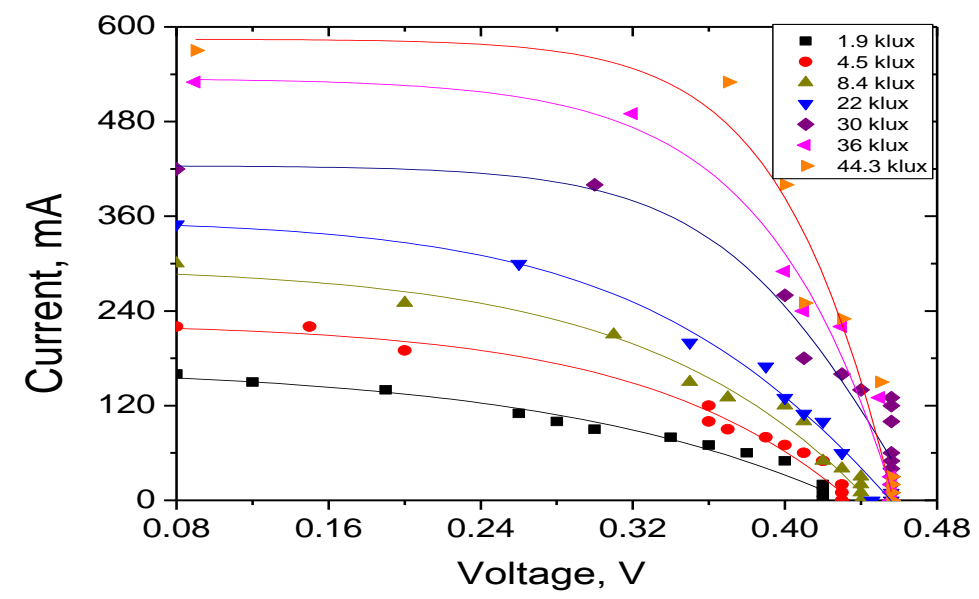

Fig. (5) Output characteristics of Sargent - Welch solar cell of $5.70 \mathrm{~cm}$ in diameter, plotted at different illumination levels ranging from 1.90 klux up to 44.30 klux.

\subsubsection{Effects of Illumination Level on Solar Cells Electrical Parameters 3.1.1.1. Short-Circuit Current and Open-circuit voltage}

The dependence of $I_{s c}$ and $V_{o c}$ of silicon solar cells on the illumination level was shown in Fig. (6). From which, it is clearly shown that, the short-circuit current increases linearly, as a function of the illumination level. On the other hand, $\mathrm{V}_{\text {oc }}$ increases with increasing the illumination level for certain range of up to around 32.22 klux. But, for higher illumination levels, a saturation condition in $\mathrm{V}_{\mathrm{oc}}$ was observed, where its value reaches around 0.456 Volt. 


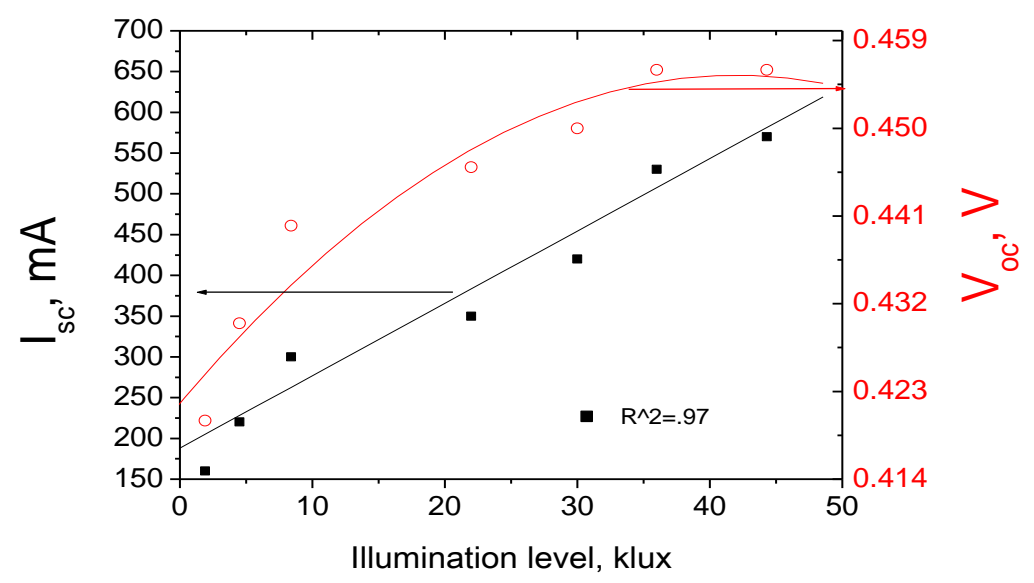

Fig. (6) Short-circuit current and open-circuit voltage dependence on illumination levels for the proposed solar cell.

\subsubsection{Maximum Output Power and Fill Factor}

The dependence of the maximum output power $\left(\mathrm{P}_{\max }\right)$ and fill factor $(\mathrm{FF})$ of silicon solar cell on the illumination levels was shown in Fig. (7). From which, it is clear that both parameters were shown to increase linearly, as a function of the illumination level.

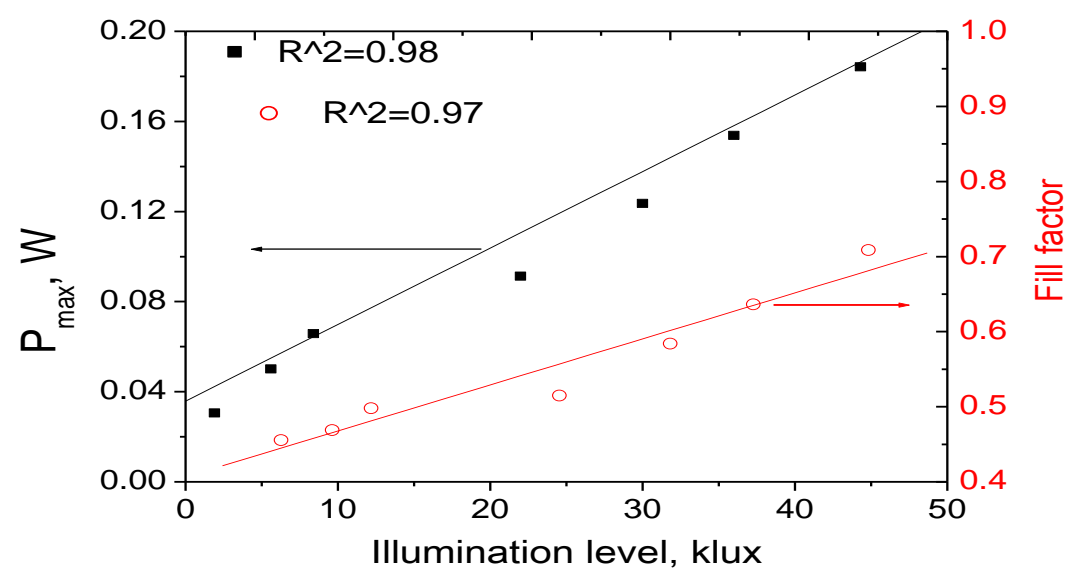

Fig. (7) Maximum output power and fill factor dependence on illumination level.

\subsection{Temperature Effects}

The dependence of the electrical performance of the proposed solar cells on temperature was studied. In this concern, the proposed sample was kept running at different illumination levels while recording their output parameters and temperature, at different operating times (Fig. 8). From which, it is clearly shown that, for illumination level of $36.0 \mathrm{klux}$, as an example, the cell temperature was increased from an initial value of $39.0{ }^{\circ} \mathrm{C}$, measured after few seconds, up to around $154.0{ }^{\circ} \mathrm{C}$, measured after 31.0 minutes. For longer illumination periods, up to around 64.0 minutes, the cell 
temperature was shown to be saturated at around $156^{\circ} \mathrm{C}$. On the other hand, for the same illumination level, $I_{s c}$ and $V_{o c}$ were plotted as a function of the operating time, as shown in Fig. (9). From which, it is clear that $\mathrm{I}_{\mathrm{sc}}$ was increased from $490.0 \mathrm{~mA}$, measured at cell temperature of $39.0{ }^{\circ} \mathrm{C}$, up to 513.9 $\mathrm{mA}$, measured at $156{ }^{\circ} \mathrm{C}$. The rate of current increase due to temperature was calculated to be around $+0.22 \mathrm{~mA} /{ }^{\circ} \mathrm{C}$ (Fig. 9a). Besides, $\mathrm{V}_{\text {oc }}$ was decreased from 0.482 Volt down to 0.215 Volt, measured within the same temperature range. The rate of decrease was calculated to be around $-2.3 \mathrm{mV} /{ }^{\circ} \mathrm{C}$ (Fig. $9 b)$. On the other hand, the maximum output power and power conversion efficiency ( $\eta$ ) of the cell were calculated and plotted, as a function of temperature, where a decreasing rates of $-0.59 \mathrm{~mW} /{ }^{\circ} \mathrm{C}$ (Fig. 10a), and $-0.065 \% /{ }^{\circ} \mathrm{C}$ (Fig. 10b) were recorded, respectively.

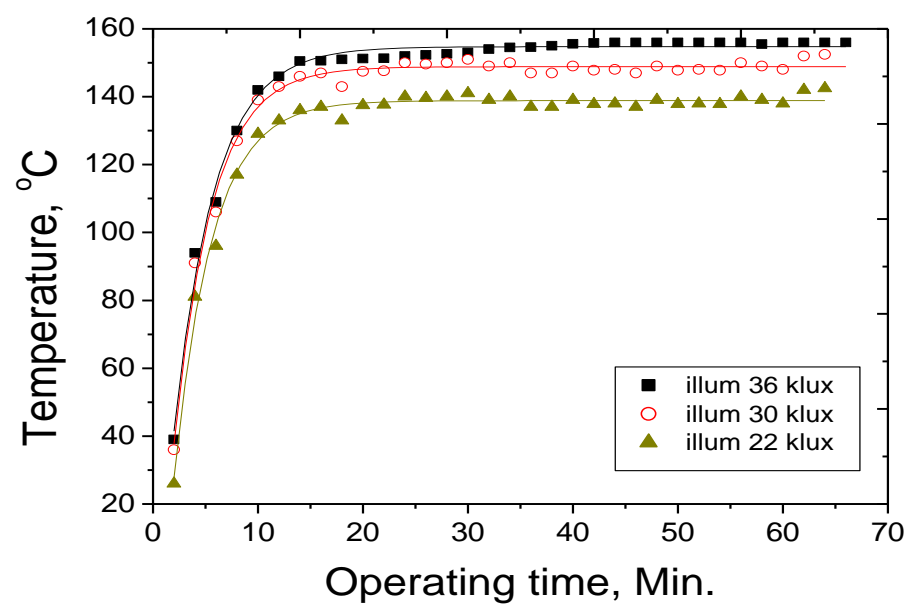

Fig. (8) Dependence of solar cell temperature on operating time, plotted at different illumination levels.

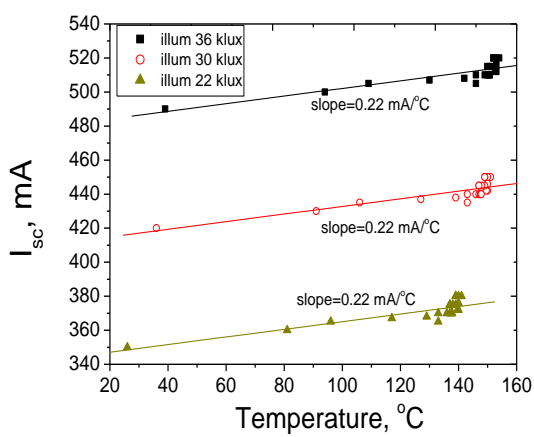

(a)

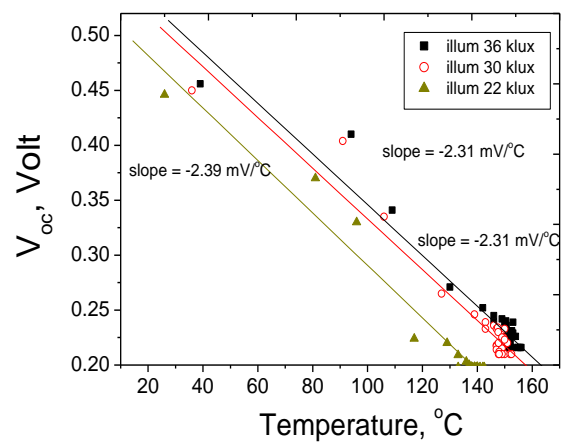

(b)

Fig. (9) Dependence of short-circuit current (a) and open-circuit voltage (b) on solar cell temperature, plotted at different illumination levels. 


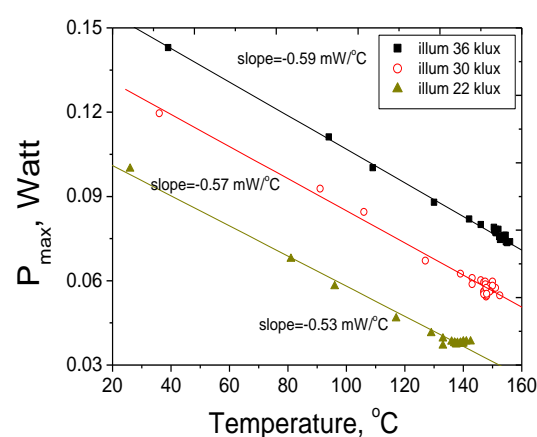

(a)

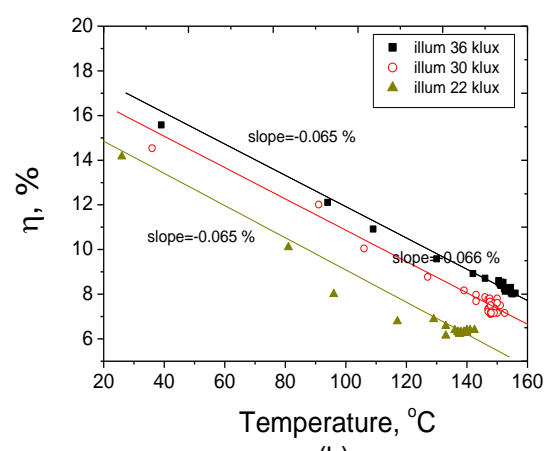

(b)

Fig. (10) Dependence of maximum output power (a) and power conversion efficiency (b) on solar cell temperature, plotted at different illumination levels.

\subsection{Improvement of Solar Cell Performance}

The present part of the work was mainly concerned with the improvement of the power conversion efficiency of the proposed silicon solar cells, applying the following hybrid techniques:

1) Solar cell/thermoelectric hybrid system (PV/TEG),

2) Solar cell/thermoelectric/passive heat sink hybrid system (PV/TEG/pHS) and

3) Solar cell/thermoelectric/active heat sink hybrid system (PV/TEG/aHS).

For the proposed solar cells, interfaced with thermoelectric devices (on the three hybrid systems), the dependence of their electrical parameters on temperature were shown in Fig`s. (11 through 13). From Fig. (11), it is clearly shown that, the initial solar cell temperature was decreased from $39.0^{\circ} \mathrm{C}$ down to $36.0{ }^{\circ} \mathrm{C}, 33.0^{\circ} \mathrm{C}$, and $28.0^{\circ} \mathrm{C}$ for the different hybrid systems, respectively. Also, after $31.0 \mathrm{~min}$, the recorded maximum temperature levels were shown to be decreased down to around $152.0^{\circ} \mathrm{C}, 126^{\circ} \mathrm{C}$, and $120.3{ }^{\circ} \mathrm{C}$, respectively.

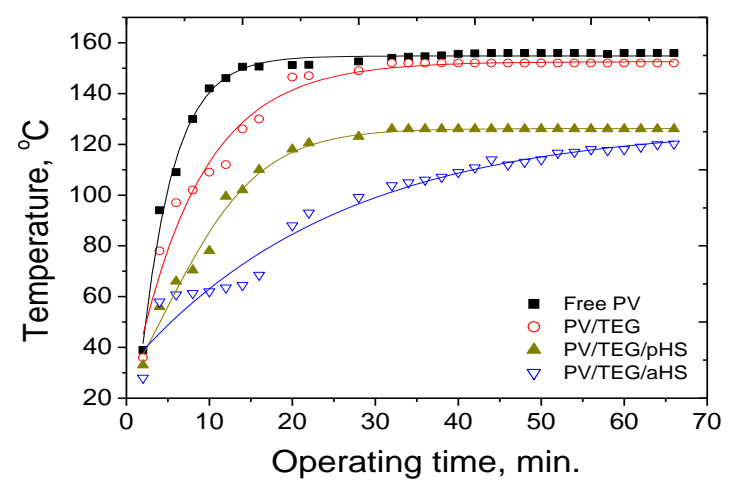

Fig. (11) Temperature of silicon solar cell arranged on different hybrid systems, plotted as function of operating time. 
On the other hand, the dependence of both $P_{\max }$ and $\eta$ on temperature were shown in Fig. (12). From which, it is clear that the rate of $\mathrm{P}_{\max }$ decrease was shown to be from $-0.59 \mathrm{~mW} /{ }^{\circ} \mathrm{C}$, down to $0.53 \mathrm{~mW} /{ }^{\circ} \mathrm{C},-0.52 \mathrm{~mW} /{ }^{\circ} \mathrm{C}$, and $-0.34 \mathrm{~mW} /{ }^{\circ} \mathrm{C}$ for the different hybrid structures, respectively. On the other hand, $\eta$ was improved from $0.065 \% /{ }^{\circ} \mathrm{C}$, measured for the free $\mathrm{PV}$, up to $-0.058 \% /{ }^{\circ} \mathrm{C}$, $0.057 \% /{ }^{\circ} \mathrm{C}$ and $0.037 \% /{ }^{\circ} \mathrm{C}$, for the three hybrid structure systems, respectively.

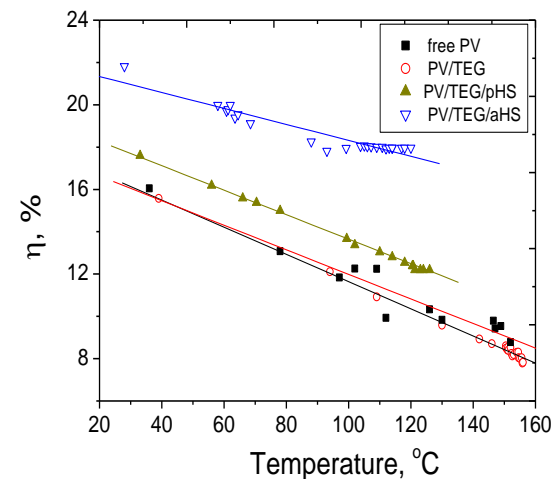

(b)

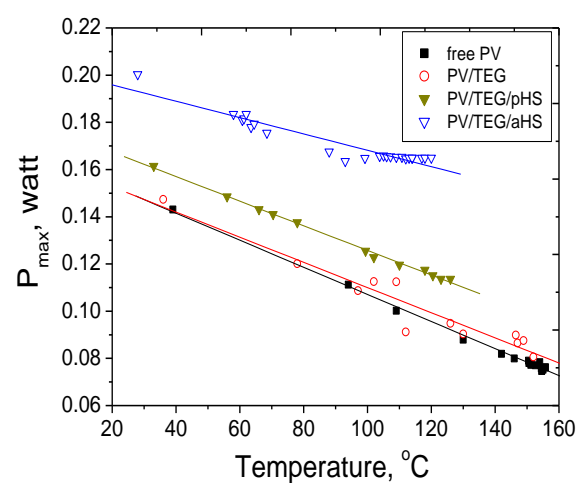

(a)

Fig. (12) Maximum output power (a), and efficiency (b) of silicon solar cells arranged on different hybrid systems, plotted as a function temperature.

The output of both the solar cell and thermoelectric [12] of the different hybrid systems was monitored, calculated, added to each other, and plotted at different temperature levels (Fig. 13). From which, it is clearly shown that, an initial total $\mathrm{P}_{\max }$ value of $0.195 \mathrm{~W}$, measured at cell temperature of $28.0{ }^{\circ} \mathrm{C}$, was shown to be decreased down to $0.166 \mathrm{~W}$, measured at $120.3{ }^{\circ} \mathrm{C}$, with a rate of decrease of $-0.3 \mathrm{~mW} /{ }^{\circ} \mathrm{C}$. On the other hand, an initial total system efficiency value of $21.1 \%$, measured at cell temperature of $28.0{ }^{\circ} \mathrm{C}$, was shown to be decreased down to $18.12 \%$, measured at $120.3{ }^{\circ} \mathrm{C}$, with a rate of decrease of $-0.033 \% / /{ }^{\circ} \mathrm{C}$.

Finally, Table (2) illustrates summary of the obtained results for the different operating conditions (free running solar cell, solar cell/thermoelectric, solar cell/thermoelectric/passive heat sink, and solar cell/thermoelectric/active heat sink).

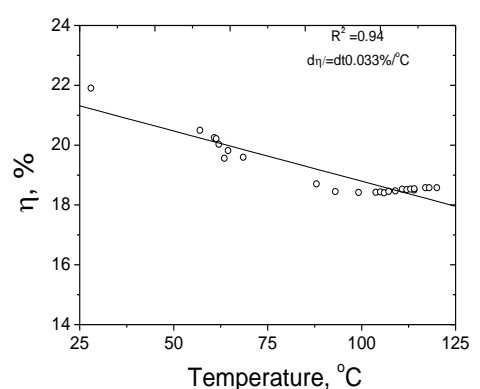

(b)

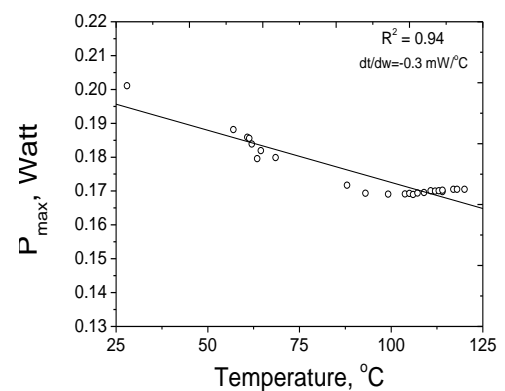

(a)

Fig. (13) Maximum output power (c), and efficiency (d) for the proposed solar cell/thermoelectric/active heat sink hybrid system, plotted as a function of temperature. 
Table. (2) Summary of the obtained results for the different operating conditions ( free running solar cell, solar cell/ thermoelectric, solar cell / thermoelectric /passive heat sink, and solar cell/thermoelectric/active heat sink).

\begin{tabular}{|c|c|c|c|c|}
\hline Condition & $\begin{array}{c}\text { Operating } \\
\text { Time }\end{array}$ & Temp., ${ }^{\circ} \mathrm{C}$ & $P, m W$ & Eff., \% \\
\hline \multirow[t]{2}{*}{ Free running PV } & Initial & 39.0 & 143.5 & 16.25 \\
\hline & End & 156.0 & 73.08 & 8.09 \\
\hline PV/pHS Hybrid & Initial & 38.1 & 146 & 15.92 \\
\hline System & End & 153.8 & 75 & 8.15 \\
\hline PV/ air & Initial & 33.5 & 157 & 17.23 \\
\hline Cooling & End & 125.0 & 107 & 11.74 \\
\hline PV/aHS Hybrid & Initial & 30.0 & 180 & 19.68 \\
\hline System & End & 123.0 & 139 & 15.17 \\
\hline PV/TEG Hybrid & Initial & 36.0 & 147.0 & 16.86 \\
\hline System & End & 152.0 & 80.0 & 8.70 \\
\hline \multirow{2}{*}{$\begin{array}{l}\text { PV/TEG/pHS } \\
\text { hybrid system }\end{array}$} & Initial & 33.0 & 161.0 & 17.59 \\
\hline & End & 124.0 & 113.0 & 12.16 \\
\hline PV/TEG/aHS & Initial & 28.0 & 193 & 21.05 \\
\hline hybrid system & End & 120.1 & 161 & 17.47 \\
\hline Total output of & Initial & 28.0 & 195 & 21.1 \\
\hline $\begin{array}{c}\text { PV/TEG/aHS } \\
\text { hybrid system } \\
\text { (in parallel) }\end{array}$ & End & 120.3 & 166 & 18.2 \\
\hline
\end{tabular}

\subsection{Conclusions}

From the experimental work, results, analysis and discussions, it could be concluded that during normal operation of silicon solar cells their electrical characteristics are greatly influenced with their temperature rise. Where, a pronounced drop on their output voltage, power, and consequently their conversion efficiency was reported. The matter was greatly improved applying different hybrid techniques, based on thermoelectric devices and passive and active heat sinks. The application of the thermoelectric devices, as a power generators, was proved to be effective as a cooling media for the 
cells, as well, for the conversion of their temperature into additive output power. Also, passive -and active -heat sinks were shown to add more enhancements on the behavior of the proposed cells.

\subsection{References}

[1]. V. Dulin, "Electron Devices", Ch.14, English translation by Mir Publ., p. 365, 1980.

[2]. S. M. Sze, "Physics of Semiconductor Devices", $2^{\text {nd }}$ Ed., Ch.14, PP. 790-800, John Wiley \& Sons, Inc., New York, U.S, 1981.

[3]. Dominique B, Zacharie K and Donatien N , "Modeling and Simulation of Photovoltaic Module Considering Single-Diode Equivalent Circuit Model in MATLAB', Intr. Jour. of Emerging Tech. and Advanced Engineering, Vol. 3, Issue 3, March 2013.

[4]. E. Raziemaska, "The Effect of Temperature on The Power Drop in Crystalline Silicon Solar Cells", Renewable Energy, Elsevier, Vol. 28, Issue 1, pp. 1-12, Jan. 2003.

[5]. M. Hanif, et al., "Studying Power Output of PV Solar Panels at Different Temperatures and Tilt Angles", ISESCO Jour. of Science and Technology, Vol. 8, No. 14, pp. 9-12, Nov. 2012.

[6]. A. Q. Malik, et al., "Influence of Temperature on the Performance of Photovoltaic PolyCrystalline Silicon Module in the Bruneian Climate', AJSTD Vol. 26, Issue 2, pp. 61-72, 2010.

[7]. E. Garnett and M. Najarian, "Thermoelectric and Photovoltaic: Integration Challenges and Benefits', MSE226-PV Materials, Dec. 2006.

[8]. A. Goetzberger, et al., "Crystalline Silicon Solar Cell', John Wiley and Sons, Ltd., Inc., New York. USA, p. 71, 1998.

[9]. Customer Thermoelectric, 11941 Industrial Park Road, STE 5, Bishopville, MD 21813, Tel.: 443-926-9135, Fax: 443-926-9137, temodule@customthermoelectric.com.

[10]. F. Khanan, S.N. Singha, and M. Husainb, "Effect of Illumination Intensity on Cell ParaMeters of a Silicon Solar Cell', Solar Energy Materials \& Solar Cells, Vol. 94, pp. 14731476, 2010.

[11]. B. Bhaskar, S. Gardas, and M. Tendolkar, "Hybrid Photovoltaic Thermal System : A state- of the art literature review', Intr. Jour. of Mech. and Prod. Eng. (IJMPE) ISSN No.: 2315-4489, Vol. 2, No. 1, 2013.

[12]. Tom Schneider, et al., "Thin Film Thermoelectric Power Generation”, Nextreme Thermal Solutions, 04-24-07,Inc, USA, May, 2007. 